\title{
Evaluation of Key Success Factors for Web Design in Taiwan's Bike Case Study
}

\author{
I-Sung LAI ${ }^{1}$, Yung-Fu HUANG ${ }^{2}$, Jie-Hua SIANG ${ }^{3}$, Ming-Wei WENG ${ }^{4 *}$
}

Received: August 01, 2020 Revised: October 05, 2020 Accepted: October 15, 2020

\begin{abstract}
Global warming awareness through energy conservation is growing due to the regulatory policies issued by governments and voluntary organization that established carbon emission limits. Transportation is one of the major contributors to carbon emissions. Bike will be simultaneously saving money, getting fit and helping to reduce global warming. Web design has been identified as a key factor for the acceptance and success of the websites and electronic commerce. The purpose of this research is to investigate the effective implementation of the proposed Analytic Hierarchy Process (AHP) technique on a bike case study whose company (Bike Company) is involved in web design for a critical component in the demonstration. Survey research used a variety of data collection methods, with the most common being questionnaires and interviews of some exporters. The research results reveal that the top five key success factors are Good reputation, Transaction security, Ease of use, Promotion, and Diversified choices, which provide the guidelines and directions for decision-makers to design effective websites in the current competitive business scenario. The major findings of this study are suggesting that Internet marketing channels are securing the company's relevance, together with paving the way for methods to increase web traffic.
\end{abstract}

Keywords: Bike Case, Web Design, AHP, Key Success Factors, Global Warming

JEL Classification Code: M30, M38, M39

\section{Introduction}

During the last several decades, there has been a rapid growth of leisure bike riding due to the awareness of environmental issues in Taiwan. The number of leisure riding in Taiwan has continued to increase in recent years.

${ }^{1}$ First Author. Ph.D. Student, Department of Business Administration, Chaoyang University of Technology, Taichung, Taiwan.

Email: Jack@lasco.com.tw

${ }^{2}$ Professor, Department of Marketing and Logistics Management, Chaoyang University of Technology, Taichung, Taiwan.

Email: huf@cyut.edu.tw

${ }^{3}$ Ph.D. Student, Department of Business Administration, Chaoyang University of Technology, Taichung, Taiwan.

Email: a0981-305846@gmail.com

${ }^{4}$ Corresponding Author. Assistant Professor, Department of Marketing and Logistics Management, Chaoyang University of Technology, Taichung, Taiwan [Postal Address: No. 168, Jifeng East Road, Wufeng District, Taichung City, 413, Taiwan]

Email: mingweiweng@gmail.com

(c) Copyright: The Author(s)

This is an Open Access article distributed under the terms of the Creative Commons Attribution Non-Commercial License (https://creativecommons.org/licenses/by-nc/4.0/) which permits unrestricted non-commercial use, distribution, and reproduction in any medium, provided the original work is properly cited.
According to Sport City report 2013, annual population of bike riders in Taiwan could reach 23.8 million. There is a system of well-marked bike paths like well-designed pedestrian networks. According to Lonely Planet, Taiwan is generally considered the most bike-friendly place in all of Asia with its dedicated cycling lanes, plethora of bikesharing schemes and a government actively promoting leisure riding. Furthermore, road safety can be a highly emotive subject and we all have opinions on what should be done to reduce crash risk on our roads. Building safe facilities for cyclists turned out to be one of the biggest factors in road safety for riders (Lonely Planet, 2012; Tourism Bureau, 2012). However, climate change is one of the world's most pressing challenges because of human emissions of greenhouse gases. Global groups of bicycle activity keep increasing. Taiwan is an island country, so the threat and impact from ocean is most direct and serious.

Dynamics methodology was used to propose a causative relationship model for the bike case (Huang, 2014). The survey was conducted by Sport City report on the export of bikes by major trading countries: America $(23.16 \%)$, U.K. (18.57\%), Netherlands (15.48\%), Germany (9.57\%), Japan 
(7.62\%), Italy (5.25\%), Belgium (4.89\%), South Korea (3.99\%), and China (3.86\%) (see Figure 1). According to Taiwan's Ministry of Economic Affairs, Taichung has a fully built-up bike manufacturing cluster (over 600 leading bike parts manufacturers in Taichung and Changhua). It is examined in the context of the e-commerce of book purchasing (Gefen, 2000). The reputation scores and retailers' photos are regarded as signals promoting trust in e-commerce (Bente et al., 2012).

Many small- and medium-sized enterprises (SMEs) have been under pressures from large firms to implement business-to-business (B2B) e-commerce information systems. The Taiwanese government has been promoting its global logistics strategy for economic development, which stresses supply chain integration by bridging information flows among overseas enterprises, domestic large firms, and local SMEs. Our main analysis centers on bike touring as a nomadic leisure practice and on how it offers a radical departure from traditional modes of structuring work and life, and thus, complicates the relationship between work and leisure. The remainder of this paper is divided into five sections. The first section deals with the introduction and development of the research. Section 2 reviews the literature. Section 3 presents the Analytic Hierarchy Process research methodology. Section 4 describes the data analysis and results on e-commerce. Section 5 describes the case study. Finally, conclusions and further research are presented in Section 6.

\section{Literature Review}

\subsection{E-commerce}

In the last decade, the Internet has changed market transactions fundamentally. E-commerce platforms, such as eBay, constitute a global marketplace accessible for everyone, anywhere. E-commerce is growing at an exponential rate. Web-enabled applications for business-to-business (B2B) electronic commerce are expected to enhance inter- organizational coordination and improve relationships among business partners. Web-based B2B e-commerce system can deliver promised benefits. Organizations need to measure and determine the impact of web-based systems on B2B process and the value to the enterprise. However, customer relationship management (CRM) and business-to-business (B2B) are essential to the success of modern business. The integration of CRM and B2B will benefit all related parties in business processes, including sales, marketing, customer service, and information support. For Kalakota and Whinston (1997) "E-commerce includes any form of business activity such as B2B (Business-to-Business), C2C (Consumer-toConsumer), B2C (Business-to-Consumer, C2B (Consumerto-Business, and $\mathrm{O} 2 \mathrm{O}$ (Online-to-Offline)."

$\mathrm{B} 2 \mathrm{~B}$ commerce includes a broad range of intercompany transactions, including wholesale trade as well as company purchases of services, resources, technology, manufacturing parts and components, and capital equipment. Turban et al. (2018) said that e-commerce is a major concern in a wide variety of business models such as B2B (Businessto-Business), $\quad \mathrm{C} 2 \mathrm{C}$ (Consumer-to-Consumer), B2C (Business-to-Consumer, C2B (Consumer-to-Business, and $\mathrm{O} 2 \mathrm{O}$ (Online-to-Offline). However, if the manufacturers are an e-commerce brand, they need some e-commerce marketing strategies to obtain new customers as well as entice old customers to keep coming back to online website. Allen and Fjermestad (2001) showed that, by integrating the new e-commerce strategy for a traditional manufacturer, an established consumer products company has begun to formulate its e-commerce strategy. Wright et al. (2006) observed that increasing use of information and communication technologies (ICT) is shifting market power from suppliers to consumers. The role of marketing strategies was developed to control consumer empowerment, which is reflected in the development of consumer-centric content based on a customer's information. Many other scholars, including Wang and Fesenmaier (2006), Lee and Park (2009), Pappas (2016), Gregory et al. (2019) have pointed out the importance of Internet marketing strategy.

\section{TOP-10 Bicycle Export by Countries 2019 (in units)}

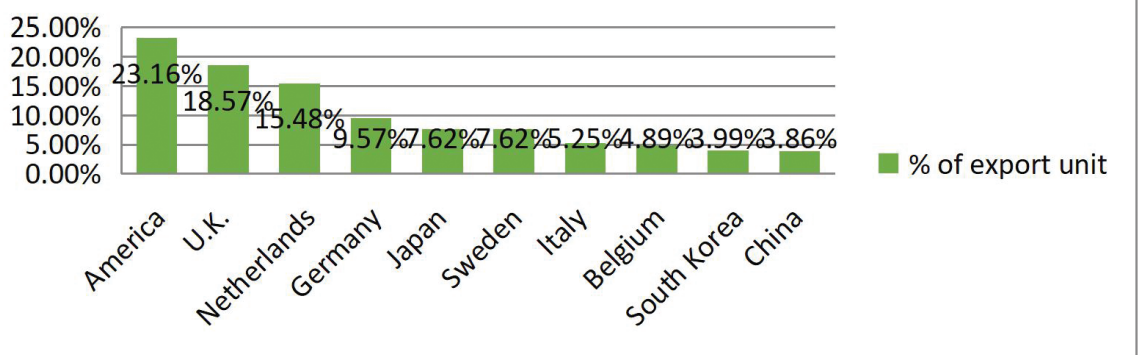

Figure 1: Number of Bicycles Exported from Taiwan in 2019, by Country 
I-Sung LAI, Yung-Fu HUANG, Jie-Hua SIANG, Ming-Wei WENG /

\subsection{Key Success Factors (KFS)}

Customer service is a key factor of success for e-commerce companies regardless of the company's size. An excellent customer service can boost customer's trust in the business. To make money online, the manufacturers have to make it as easy for new customers to buy. Easy navigation, clear headers, correct spelling, and a visually pleasing look all contributes to a website visitors will stick around to explore. Early theorization of Key Success Factors (KFS) can be traced back to Daniel (1961) and Rockart (1979). Asgari et al. (2012) presented the development of a framework for improving e-business through key success factors of knowledge management process in Malaysia. Colla and Lapoule (2012) provided an original analytical approach to the identification of the critical success factors of large grocery retailers developing drive-in services. Delphic Hierarchy Process (DHP) was designed to find out the key success factors of e-commerce in the travel industry (Yang et al., 2012).

The key success factors (KFS) concept was implemented in mobile commerce (Feng et al., 2006). The characteristics of potential $\mathrm{m}$-commerce users include the examination of the key success factors of m-commerce (Lee \& Lee, 2007). Web design has been critically important in laying the groundwork for understanding how visitors browse the e-commerce website. The KFS of web design was explored for its influence on online user's perceptions and behaviors on an e-commerce website (Flavián et al., 2006). Korgaonkar et al. (2009) investigated critical factors involved in building a successful website. Alford et al. (2014) evaluated the perceived usability of new website and identified the key factors affecting customers' intention to use the new website. Molinillo et al. (2020) explored the influence of social support and community factors on customer engagement and the subsequent effects on customer loyalty toward social commerce websites. KFS can be used in different fields of applications (Zhou et al., 2011; Prougestaporn et al., 2015; Trang et al. 2020).

\subsection{Web design}

Web design has been identified as a key factor for the acceptance and success of the websites and e-commerce. More people today are using their mobile phone to purchase products online. People are no longer using laptops or desktops for interaction and online shopping. Designing the e-commerce website to be mobile friendly is crucial. However, with evolving technologies, many companies are also struggling with how to effectively create a meaningful user experience across multiple channels. By now company website and online store should already be accessible on mobile devices, but that doesn't automatically mean the business is ready for mobile commerce. Visitors to e-commerce sites of companies who might take a multiscreen approach only browse for products on mobile, and they might later complete the purchase on their desktops. Rosenfeld and Morville (1997) emphasized the need for increased attention to user satisfaction as a key factor in designing websites.

Lin and $\mathrm{Lu}$ (2000) identified why users accept or reject a website and how user's acceptance is affected by features (e.g., information quality of the website, response time and system accessibility) with technology acceptance model (TAM). Aladwani and Palvia (2002) developed key characteristics of website quality: specific content, content quality, appearance, and technical adequacy. Shchiglik and Barnes (2004) examined a perceived airline website quality instrument (PAWQI) that attempts to provide some initial direction in this area. Herring et al. (2004) presented the properties of the emergent blog genre, and situate it with respect to offline genres, as well as with respect to the broader genre ecology of the Internet. Stover (2007) described how to create a blog marketing strategy utilizing a set of basic marketing variables - the marketing mix. Sahi (2015) explored the linkages between different dimensions of website usability and their impact on user satisfaction.

Various dimensions to user satisfaction such as user interface, variety of information, community, online reservations, entertainment, irritation, and credibility, have been identified (Wan 2002; Brackett \& Carr, 2001; Rau et al., 2006; Robin et al., 2004). Nowadays, website should do much more. Website is part of the marketing strategy and must offer a lot more to visitors, not only inform them, but encourage them to take action: buy, learn, contact. Does your website do that? Stover (2007) presented the criticism on the 4Ps Web-Marketing Mix framework, the most popular tool of traditional marketing management. Fan and Tsai (2010), Alford et al. (2014), among others, demonstrated the influence of website design quality and marketing strategy. Others including McKinney et al. (2002), Cyr (2008) have pointed out high-performance navigation, appearance, and layout are of central interest in the context of web-design.

Performance measurement has become a major issue in recent year. Early performance measurement focused mainly on financial measures. A majority of performance measurement have used input and outcome data to assess project performance using the AHP and TOPSIS approaches. Most AHP have invested heavily in application services providers (ASP). The readers are referred to good tutorials in security, integration, pricing customer service, and company financial position for an introduction to the above approaches and their applications. Lee and Kozar (2006) investigated websites quality factors, their relative important in selecting the most preferred website, and the relationship between website preference and financial 
performance. Dominic et al. (2010) have noted that applying the AHP approach for the e-government websites in Asia marks a significant acceleration of implementation, raising the overall effectiveness. Büyüközkan et al. (2019) proposed the AHP approach is applied on a case study to measure the performance of the web-based services of ten different healthcare institutions in Turkey. Dahliah et al. (2020) analyzed the strategy of determining economic development planning on SME improvement in Indonesia. Harshan et al. (2017) engaged in scientific discussion on the feasibility of AHP approach based on multi-criteria decision-making methodology to evaluate the performance quality of library websites. Li and Sun (2020) employed multi-criteria decision-making (MCDM) and to minimize any ambiguity and greyness in the decision-making with FAHP and TOPSIS-Grey. Numerous studies (Yu et al., 2011; Nagpal et al., 2015a, 2016b; Masudin and Saputro, 2016, Sindhu et al., 2017; Roy et al. 2018; Gaur et al., 2018; Aggarwal and Aakash, 2018; Rouyendegh et al., 2019; Bokolo, 2019; Kahraman et al., 2020; Nguyen et al., 2020; Kim et al. 2020) stress that AHP is fundamental for the evaluation of websites.

\section{Research Methodology}

This study employed the AHP approach to gain an indepth and holistic understanding of the web-design process. In keeping with the tradition in quantity research, we aimed for rich descriptions of the individual cases, while also attempting to identify some general trends and significant patterns.

\subsection{AHP Induction}

The Analytic Hierarchy process (AHP) was developed to try and evaluate several evaluation criteria in order to systemize complex problems. Early theorization of AHP can be traced back to Saaty (1977). Saaty (1986) posited that AHP is a method of measurement with ratio scales and illustrated it with two samples. The AHP is a standardized measure designed to predict the weight of every factor from the lower level to the higher level. As shown in Table 1, the comparisons, in a scale ranging from 1 to 9 , correspond to the level of dominance or contribution to the study.

The implementation procedure of AHP was as follows, consisting of main steps for assessing website design performance.

Step 1: Structure the decision hierarchy from the top with the decision of a goal, then the objectives from a broad perspective.

Step 2: Construct a set of pairwise comparison matrices. Each element in an upper level used to compare the elements proposed by White (1987).

$$
A=\left[\begin{array}{ccc}
1 & \cdots & a_{n 1} \\
\frac{1}{a_{21}} & \cdots & a_{n 2} \\
\frac{1}{a_{31}} & \cdots & a_{n 3} \\
\vdots & \ddots & \vdots \\
\frac{1}{a_{n 1}} & \cdots & 1
\end{array}\right]_{n \times n}
$$

The diagonal elements in the matrix $A$ are self-compared of the website design, thus $a_{i j}=1$, where $i=\mathrm{j}, i, j=1,2, \cdots, \mathrm{n}$. The values on the left and right sides of the matrix diagonal represent the strength of the relative importance degree of the $i$ th element compared to the $j$ th element. Let $a_{i j}=1 / a_{j i}$, where $a_{i j}>0, i \neq \mathrm{j}$.

Step 3: Determine the normalized decision matrix and construct weights of alternatives. Let $w_{i}$ denote the importance degree for the $i$ th attribute of website design, then

$$
\begin{gathered}
c_{i j}=\frac{a_{i j}}{\sum_{j=1}^{n} a_{i j}}, \\
w_{i}=\sum_{j=1}^{n} \frac{c_{i j}}{n} \\
W=\left[\begin{array}{c}
w_{1} \\
w_{2} \\
\vdots \\
w_{n}
\end{array}\right]
\end{gathered}
$$

Step 4: Calculation of Matrix Consistency: the Consistency Ratio (CR) formula introduced by Saaty is used in measuring the consistency, and it is expected to be smaller than 0.10 . RI values, which can be calculated as matrixes.

$$
\text { Consistency Ratio }=\frac{\text { Consistency } \operatorname{Index}(\mathrm{CI})}{\text { Random Index }(R I)}
$$

The index of CI equation is given in Equation (5)

$$
\mathrm{CI}=\lambda_{\max }-\mathrm{n} /(\mathrm{n}-1)
$$

Step 5: Determine the relative overall requirement of customer requirement degrees.

If $C R>0.10$, it is accepted that the comparison matrix is inconsistent. In this situation, the comparison matrix is revised, and the necessary arrangements are made for its consistency (Sariçali \& Kundakci, 2016). 


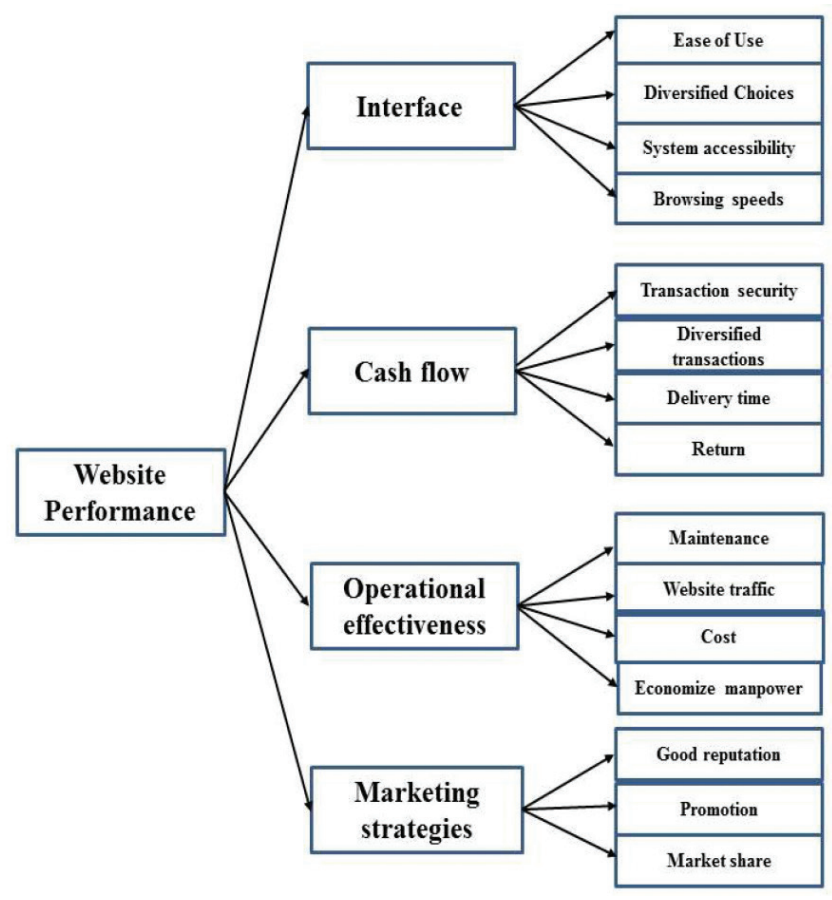

Figure 2: The Framework for Website Evaluation

\subsection{Review of Constructs Used in the Study}

Various researchers have suggested user satisfaction as one of the most important dependent variables for measuring success in e-commerce. As an online business owner, website design is the most important factor in choosing an e-commerce platform. It is what sets the first impression, draws customers to login, and tells the story of your brand. The study covers the front end of a website from Delone and Mclean (2003); marketing strategies using Hamill (1997), Ghosh (1998); cash flow in Duffy and Dale (2002), Wan (2000); and operational effectiveness using Ramanathan et al. (2012).

For the present research, the framework for website evaluation has been briefly described in Figure 2. It indicated four main evaluation dimensions - interface, cash flow, operational effectiveness, and marketing strategies related to website service to manufacturer. The purpose of this framework is to test website quality and performance.

\subsection{Participants}

The subject was asked to fill out a questionnaire to elicit information concerning his attitude and professional knowledge of the bike case, including nine consultants and nine university professors. They came from various regions of Taiwan. Their ages ranged from fifty to sixty years old.

\section{Data Analysis and Results}

The survey instrument for the study was developed based on published studies on the website. Data came from each small- and medium-sized enterprise interviewed indepth during an average of two hours each. The first round of the study involved semi-contracture questionnaire, which included four key success factors from the literature and these were judged by the experts required to indicate the level of agreement with each of them on a scale from (1) equal importance; (3) moderate importance of one over another; (5) essential or strongly important; (7) very strongly important; (9) extremely important. There were intermediate values (2),(4),(6),(8) between the two adjacent judgments. The results are in Table 1 and Table 2.

Further, the result of weights analysis of indicators for the study was developed based on published studies. We identified the global rank of KFS and it is shown on Table 2. The relative weights of all behavioral indicators are shown in Table 2. The 15 behavioral indicators in descending order are good reputation (the highest rank $=1$ ); transaction security (the rank=2); ease of use (the rank=3); promotion (the rank=4); diversified choices (the rank $=5$ ); diversified transactions (the rank=6); delivery time (the rank=7); system accessibility (the rank=8); market share (the rank=9); browsing speeds (the rank=10); return (the rank=11); economize manpower (the rank=12); maintenance (the rank=13); website traffic (the rank=14); and cost (the rank=15). 
Table 1: Pairwise Comparison Scale

\begin{tabular}{|l|l|}
\hline Rating & \multicolumn{1}{|c|}{ Description } \\
\hline 1-Equal & Both alternatives have equal importance. \\
\hline 3-Moderate & One of the alternatives is slightly more important than the other one. \\
\hline 5-Strong & One of the alternatives is strongly more important than the other one. \\
\hline 7-Very Strong & One of the alternatives is very strongly important compared to the other one. \\
\hline 9-Extreme importance & One of the alternatives is strictly superior to the other one. \\
\hline
\end{tabular}

Table 2: Weight Analysis of Overall Indicators

\begin{tabular}{|c|c|c|c|c|c|c|}
\hline Dimensions & Weight & Sub-dimensions & Weight & Rank & Overall weight & Overall rank \\
\hline \multirow[t]{4}{*}{ Interface } & 0.63 & Ease of use $\left(\mathrm{I}_{11}\right)$ & 0.0507 & 1 & 0.0269 & 3 \\
\hline & & Diversified choices $\left(\mathrm{I}_{12}\right)$ & 0.0265 & 2 & 0.0140 & 5 \\
\hline & & System accessibility $\left(\mathrm{I}_{13}\right)$ & 0.0147 & 3 & 0.078 & 8 \\
\hline & & Browsing speeds $\left(\mathrm{I}_{14}\right)$ & 0.0080 & 4 & 0.043 & 10 \\
\hline \multirow[t]{4}{*}{ Cash flow } & 0.351 & Transaction security $\left(\mathrm{I}_{21}\right)$ & 0.0529 & 1 & 0.0133 & 2 \\
\hline & & Diversified transactions $\left(\mathrm{I}_{22}\right)$ & 0.0246 & 2 & 0.0620 & 6 \\
\hline & & Delivery time $\left(\mathrm{I}_{23}\right)$ & 0.0148 & 3 & 0.0370 & 7 \\
\hline & & Return $\left(\mathrm{I}_{24}\right)$ & 0.0078 & 4 & 0.0200 & 11 \\
\hline \multirow[t]{4}{*}{$\begin{array}{l}\text { Operational } \\
\text { effectiveness }\end{array}$} & 0.258 & Maintenance $\left(\mathrm{I}_{31}\right)$ & 0.0055 & 1 & 0.087 & 13 \\
\hline & & Website traffic $\left(\mathrm{I}_{32}\right)$ & 0.0024 & 2 & 0.038 & 14 \\
\hline & & $\operatorname{Cost}\left(I_{33}\right)$ & 0.0014 & 3 & 0.022 & 15 \\
\hline & & Economize manpower $\left(\mathrm{I}_{34}\right)$ & 0.0074 & 4 & 0.012 & 12 \\
\hline \multirow[t]{3}{*}{$\begin{array}{l}\text { Marketing } \\
\text { strategies }\end{array}$} & 0.161 & Good reputation $\left(I_{41}\right)$ & 0.0606 & 1 & 0.037 & 1 \\
\hline & & Promotion $\left(\mathrm{I}_{42}\right)$ & 0.0268 & 2 & 0.016 & 4 \\
\hline & & Market share $\left(\mathrm{I}_{43}\right)$ & 0.0126 & 3 & 0.008 & 9 \\
\hline
\end{tabular}

Let us consider the following Table 3. The subdimension analysis the Interface shows Ease of Use (50.7\%), Diversified Choices (26.5\%), System Accessibility (14.7\%), and Browsing Speeds (8\%), respectively. Among the subdimensions of Cash Flow, the relative importance was Transaction Security (52.9\%), Diversified Transactions (24.6\%), Delivery Time (14.7\%), and Return (7.8\%). Among the sub-dimensions of Operational Effectiveness, the relative importance was Maintenance (55\%), Website Traffic (23.9\%), Cost (13.7\%), and Economize Manpower (7.4\%). In the dimension of Marketing Strategies, the relative importance was Good Reputation (60.6\%), Promotion (26.8\%), and Market Share (12.6\%). Similarly, comparing the attribute values of all the alternatives, we can rank them accordingly.

\section{Case Study}

In developed countries like Taiwan, Japan, and Korea, most people ride bikes for leisure. They emphasize the implementation of high-quality materials and personnel. Lunge industry Co., Ltd was established in 1978 in Taiwan by a group of young people who have mechanical knowledge and skills, but more importantly, enthusiasm for the bike. The manufacturer has been set up and formed the brand LASCO (LC). LC is dedicated to produce quality chain wheel and crankset for all levels of riders. It was formed in 2002, LC with the intent of running business courses on technology and business impact, and join the Top 100 businesses (SMEs) in bikes industry. 
I-Sung LAI, Yung-Fu HUANG, Jie-Hua SIANG, Ming-Wei WENG /

Table 3: Analysis of Matrix and Weight of Interface Dimension, Cash Flow Dimension, Operational Effectiveness Dimension, and Marketing Strategies Dimension

\begin{tabular}{|c|c|c|c|c|c|c|c|c|}
\hline Dimension & Sub-dimensions & & & & & & & \\
\hline \multirow[t]{5}{*}{ Interface } & & & $I_{11}$ & $\mathrm{I}_{12}$ & $\mathrm{I}_{13}$ & $\mathrm{I}_{14}$ & Weight & Rank \\
\hline & Ease of Use $\left(I_{11}\right)$ & $\mathrm{I}_{11}$ & 1 & 5 & $1 / 6$ & 5 & $50.7 \%$ & 1 \\
\hline & Diversified Choices $\left(I_{12}\right)$ & $\mathrm{I}_{12}$ & $1 / 5$ & 1 & 8 & 8 & $26.5 \%$ & 2 \\
\hline & System Accessibility $\left(\mathrm{I}_{13}\right)$ & $\mathrm{I}_{13}$ & 6 & $1 / 8$ & 1 & 8 & $14.7 \%$ & 3 \\
\hline & Browsing Speeds $\left(I_{14}\right)$ & $\mathrm{I}_{14}$ & $1 / 5$ & $1 / 8$ & $1 / 8$ & 1 & $8 \%$ & 4 \\
\hline \multicolumn{9}{|l|}{$C R=0.0034<0.1$} \\
\hline \multirow[t]{5}{*}{ Cash Flow } & & & $\mathrm{I}_{21}$ & $\mathrm{I}_{22}$ & $\mathrm{I}_{23}$ & $\mathrm{I}_{24}$ & Weight & Rank \\
\hline & Transaction Security $\left(\mathrm{I}_{21}\right)$ & $\mathrm{I}_{21}$ & 1 & 6 & $1 / 7$ & $1 / 4$ & $52.9 \%$ & 1 \\
\hline & Diversified Transactions $\left(\mathrm{I}_{22}\right)$ & $\mathrm{I}_{22}$ & $1 / 6$ & 1 & 5 & 8 & $24.6 \%$ & 2 \\
\hline & Delivery Time $\left(\mathrm{I}_{23}\right)$ & $\mathrm{I}_{23}$ & 7 & $1 / 5$ & 1 & 7 & $14.7 \%$ & 3 \\
\hline & Return $\left(I_{24}\right)$ & $\mathrm{I}_{24}$ & 4 & $1 / 8$ & $1 / 7$ & 1 & $7.8 \%$ & 4 \\
\hline \multicolumn{9}{|l|}{$C R=0.0014<0.1$} \\
\hline \multirow[t]{5}{*}{$\begin{array}{l}\text { Operational } \\
\text { Effectiveness }\end{array}$} & & & $I_{31}$ & $I_{32}$ & $I_{33}$ & $I_{34}$ & Weight & Rank \\
\hline & Maintenance $\left(\mathrm{I}_{31}\right)$ & $\mathrm{I}_{31}$ & 1 & 9 & $1 / 3$ & 5 & $55 \%$ & 1 \\
\hline & Website Traffic $\left(\mathrm{I}_{32}\right)$ & $\mathrm{I}_{32}$ & $1 / 9$ & 1 & 4 & $1 / 9$ & $23.9 \%$ & 2 \\
\hline & Cost $\left(I_{33}\right)$ & $\mathrm{I}_{33}$ & 3 & $1 / 4$ & 1 & 6 & $13.7 \%$ & 3 \\
\hline & Economize Manpower $\left(\mathrm{I}_{34}\right)$ & $\mathrm{I}_{34}$ & $1 / 5$ & 9 & $1 / 6$ & 1 & $7.4 \%$ & 4 \\
\hline \multicolumn{9}{|l|}{$C R=0.027<0.1$} \\
\hline \multirow[t]{4}{*}{$\begin{array}{l}\text { Marketing } \\
\text { Strategies }\end{array}$} & & & $\mathrm{I}_{41}$ & $\mathrm{I}_{42}$ & $\mathrm{I}_{43}$ & & Weight & Rank \\
\hline & Good Reputation $\left(I_{41}\right)$ & $\mathrm{I}_{41}$ & 1 & 8 & 6 & & $60.6 \%$ & 1 \\
\hline & Promotion $\left(\mathrm{I}_{42}\right)$ & $\mathrm{I}_{42}$ & $1 / 8$ & 1 & 5 & & $26.8 \%$ & 2 \\
\hline & Market Share $\left(\mathrm{l}_{43}\right)$ & $\mathrm{I}_{43}$ & $1 / 6$ & $1 / 5$ & 1 & & $12.6 \%$ & 3 \\
\hline$C R=0.024<0.1$ & & & & & & & & \\
\hline
\end{tabular}

Here, we introduce a well-established bike manufacturing firm in Taiwan. This firm handles its own branding through its own sales channels. The firm is equipped with advanced machinery for CNC machining, cutting, and stamping, which allows Flexible Manufacturing System (FMS), 2D CAD drawing, 3D CAD modeling, and Configuration to Order (CTO). The goal of LC website is to provide useful information about their products and services to potential clients as well as leads generation via forms and phone calls. The existing website was developed using old technology and the design was not mobile-friendly. LC needed a strong website marketing strategy. Web design has drastically changed the way the LC website builds and promotes the company brands as more and more consumers are engaging with brands online before making the purchase. The new web design was launched in 2019 and showed improved results in the first month of going live. Figure 3 presents the annual number of visitors to website from 2016 to 2020. Over this period the number of visitors showed an overall increase, reaching a peak in 2020 at approximately 4,257. Mistry et al. (2016) studied different network monitoring approaches and different tools that monitor and analyze network traffic. 


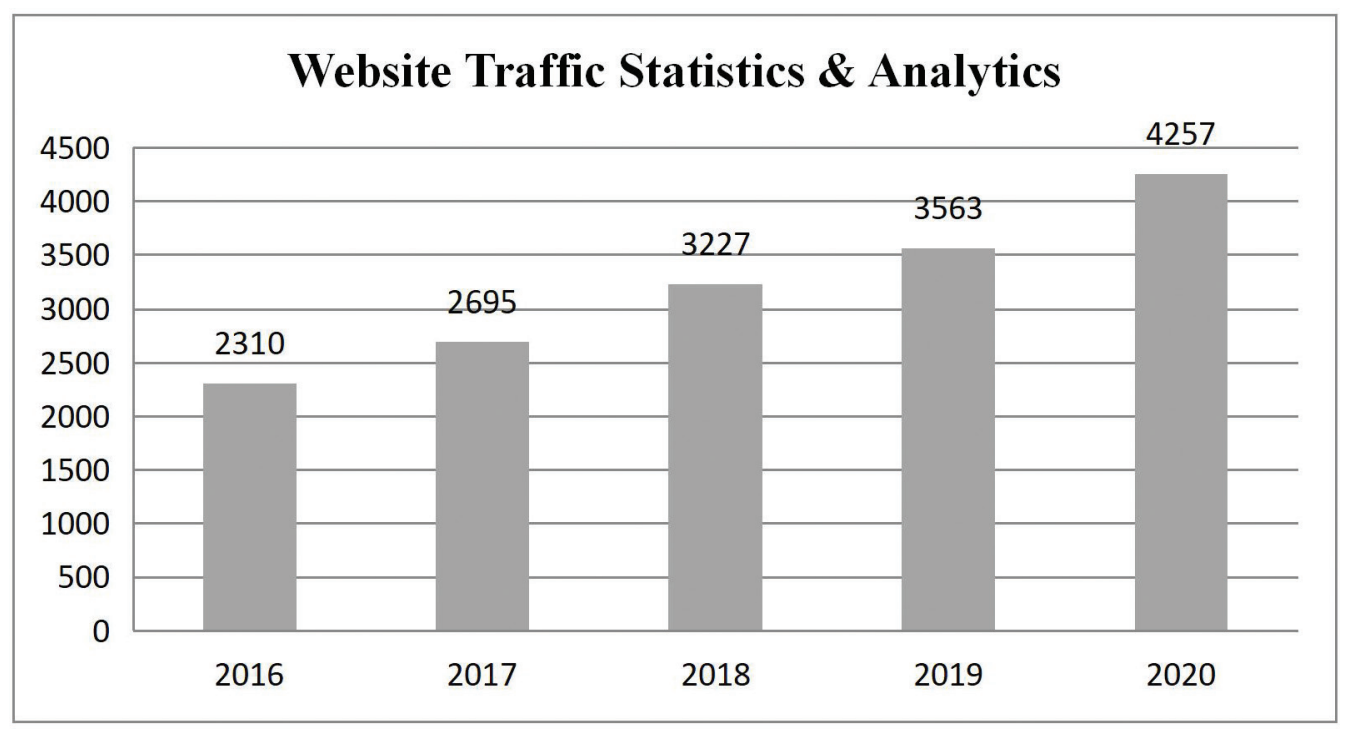

Figure 3: Website Traffic Statistics \& Analytics

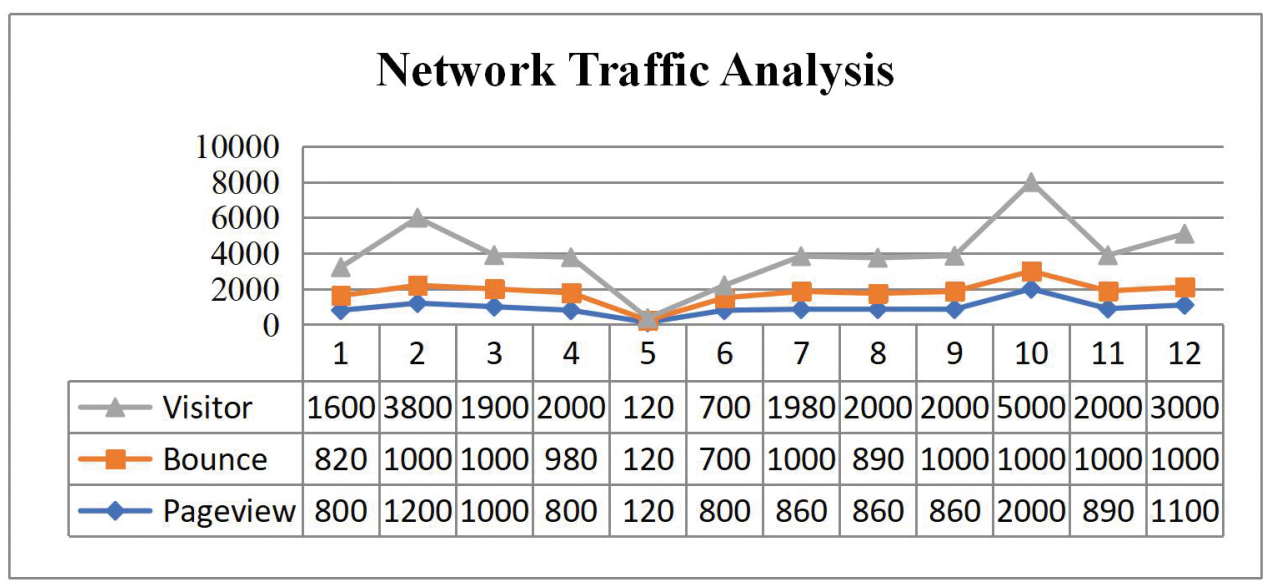

Figure 4: Network Traffic Analysis

Global marketing is the act of focusing a product on the needs of potential customers in the other countries. Typically, a global marketing strategy requires a company create an e-commerce website, and then localize the brand to reflect the needs of those communities. It is true that e-commerce still faces numerous challenges in operating overseas (e.g., in foreign emerging markets, they encounter even stronger interventions by host governments than traditional multinationals). Singh et al. (2005) investigated the internationalization speed of e-commerce companies through multiple regression analysis. Leitner and Grechening (2008) presented the results of an extended analysis of collaborative shopping networks and demonstrate the development of a representative interaction model. Figure 4 presents network traffic analysis in one year. Approximately 3,000 visitors,
1,000 bounce, and 1,100 pages were viewed in December, and remaining visitors were relatively distributed across November $(2000,1000,890)$, October $(5000,1000,2000)$, September (2000, 1000, 860), August $(2000,890,860)$, July $(1980,1000,860)$, June $(700,700,800)$, May $(120,120,120)$, April (2000, 980, 800), March (1900, 1000, 1000), February $(3800,1000,1200)$, January $(1600,820,800)$.

\section{Conclusions}

The evaluation of the success of e-commerce business requires appropriate metrics. The proposed framework, in order to take into account the KFS of web design in the bike case, makes use of AHP techniques for measuring and quantifying user satisfaction. The five major KFS 
for implementation were: Good reputation (0.0606), Transaction security (0.0529), Ease of use (0.0507), Promotion (0.0268), and Diversified choices (0.0265). The findings of this research should lead to a taxonomy of attributes, which will improve the evaluation criteria among the information staff of the bike manufacturer. It implied that, if you want your website to attract customers and business, you need to provide a high-quality experience. Designing a website plays a vital role in the network marketing business; an attractive website for customers presentation and inquiries is a must and so is a personalized design marketing. On the other hand, reputation helps customers know that you are an authority and expert products such as good online reviews and consistent information. A perfect design does not only keep visitors busy on the website, but it helps acquire new customers using banners, lead campaigns, landing pages, etc.; clicks directed from these can create public awareness on manufacturer's brand and thereby improving the growth rate of the network. Future work will hopefully clarify this important sustainable business, as a green business concern.

\section{References}

Aggarwal, A. G., \& Aakash, A. (2018). An innovative B2C e-commerce websites selection using the ME-OWA and Fuzzy AHP. Proceedings of the First International Conference on Information Technology and Knowledge Management (pp. 13-19), New Delhi, India, December 22-23.

Aladwani, A. M., \& Palvia, P. C. (2002). Developing and validating an instrument for measuring user-perceived web quality. Information \& Management, 39(6), 467-476. https://doi. org/10.1016/S0378-7206(01)00113-6/

Alford, P., Yanqing, D., \& Jacqui, T. (2014). An analysis of the key factors affecting the success of a re-launched destination marketing website in the UK. Information and Communication Technologies in Tourism, 637-649. https://doi.org/10.1007/9783-319-03973-2 46.

Allen, E., \& Fjermestad, J. (2001). E-commerce marketing strategies: an integrated framework and case analysis. Logistics Information Management, 14(1/2), 14-23. https://doi. org/10.1108/09576050110360106.

Asgari, A. A. Hamid, A. B. A., Rahman, N. M. N. A., \& Asgari, A. (2012). The role of knowledge management's KSF in the Malaysian e-business environment. Advanced in Modern Management Journal, 1(1), 11-16.

Bente, G., Baptist, O., \& Leuschner, H. (2012). To buy or not to buy: Influence of seller photos and reputation on buyer trust and purchase behavior. International Journal Human Computer Studies, 70(1), 1-13. https://doi.org/10.1016/j. ijhcs.2011.08.005.

Brackett, L. K., \& Carr, B. N. (2001). Cyberspace advertising vs. other media: consumer vs. mature student attitudes. Journal of Advertising Research, 41(5), 23-32. http://www. journalofadvertisingresearch.com/content/41/5/23.
Bokolo, A. J. (2019). Validating the usability attributes of AHP-software risk prioritization model using partial least square-structural equation modeling. Journal of Science and Technology Policy Management, 10(2), 404-430.

Bureau, T. (2012). Time for Taiwan. Retrieved from: http://taiwan. net.tw/m1. aspx?sNo=0019916.

Büyüközkan, G., Feyzioğlu, O., \& Havle, C. A. (2019). Intuitionistic fuzzy AHP based strategic analysis of service quality in digital hospitality industry. IFAC, 52(13), 1687-1692. https://doi. org/10.1016/j.ifacol.2019.11.443.

Colla, E., \& Lapoule, P. (2012). Key success factors and competitive advantages of grocery click and drive French operators. EAERCD Conference, Valencia.

Cyr, D. (2008). Modeling website design across cultures: Relationships to trust satisfaction and e-loyalty. Journal of Management Information Systems, 24(4), 47-72. https://www. tandfonline.com/doi/abs/10.2753/MIS0742-1222240402.

Daniel, D. R. (1961). Management information crisis. Harvard Business Review, 39(5), 111-121.

Dahliah, D., Kurniawan, A., \& Putra, A. H. P. K. (2020). Analysis and strategy of economic development policy for SMEs in Indonesia. Journal of Asian Finance, Economics and Business, 7(5), 103-110. https://doi.org/10.13106/jafeb.2020.vol7.no5.103

DeLone, W., \& McLean, E. (2003). The DeLone and McLean model of information systems success: a ten-year update. Journal of Management Information Systems, 19(4), 9-30. https://doi.org/ 10.1080/07421222.2003.11045748.

Dominic, P. D. D., Jati, H., \& Kannabiran, G. (2010). Performance evaluation on quality of Asian e-government websites-An AHP approach. International Journal of Business Information Systems, 6(2), 219-239.

Duffy, G., \& Dale, B. G. (2002). E-commerce processes: a study of criticality. Industrial Management \& Data Systems, 102(8), 432-441. https://doi.org/10.1108/02635570210445862.

Fan, W. S. \& Tsai, M. C. (2010). Factors driving website success - the key role of Internet customisation and the influence of website design quality and Internet marketing strategy. Total Quality Management \& Business Excellence, 21(11), 11411159. https://doi.org/10.1080/14783363.2010.529335.

Feng, H., Hoegler, T., \& Stucky, W. (2006, June). Exploring the critical success factors for mobile commerce. In: 2006 International Conference on Mobile Business (ICMB '06). June 26-27. Copenhagen, Denmark: IEEE Publishing. DOI: 10.1109/ ICMB.2006.15.

Flavián, C., Guinalíu, M., \& Gurrea, R. (2006). The role played by perceived usability, satisfaction and consumer trust on website loyalty. Information \& Management, 43(1), 1-14. https://doi. org/10.1016/j.im.2005.01.002.

Gaur, L., \& Anshu, K. (2018). Consumer preference analysis for websites using e-TailQ and AHP. International Journal of Engineering \& Technology, 7(2), 14-20.

Gefen, D. (2000). E-commerce: the role of familiarity and trust. Omega,28(6),725-737.https://doi.org/10.1016/S0305-0483(00) 00021-9. 
Ghosh, S. (1998). Making business sense of the internet. Harvard Business Review, 76(2), 126-136.

Gregory, G. D., Ngo, L. V., \& Karavdic, M. (2019). Developing e-commerce marketing capabilities and efficiencies for enhanced performance in business-to-business export ventures. Industrial Marketing Management, 78, 146-157. https://doi. org/10.1016/j.indmarman.2017.03.002.

Hamill, J. (1997). The Internet and international marketing. International Marketing Review, 14(5), 300-323. https://doi. org/10.1108/02651339710184280.

Harshan, R. K., Chen, X., \& Shi, B. (2017). Analytic hierarchy process (AHP) based model for assessing performance quality of library websites. Information Technology Journal, 16(1), 3543. DOI: 10.3923/itj.2017.35.43.

Herring, S. C., Scheidt, L. A. \& Wright, S. B. E. (2004, January). Bridging the gap: a genre analysis of weblogs. In: 37th Annual Hawai'i International Conference on System Sciences (HICSS-37), Los Alamitos: IEEE Computer Society Press, 118-131. DOI: 10.1109/HICSS.2004.1265271.

Huang, H. H. (2014, September). A causal model of the bicycle industry development- The case in Taiwan. In: 2014 IEEE International Conference on Management of Innovation and Technology (pp. 412-417). IEEE. DOI: 10.1109/ ICMIT.2014.6942462.

Kahraman, C., öztayşl, B., \& Onar, S. Ç. (2020). An integrated intuitionistic Fuzzy AHP and TOPSIS approach to evaluation of outsource manufacturers. Journal of Intelligent System, 29(1), 283-297. https://doi.org/10.1515/jisys-2017-0363.

Kalakota, R., \& Whinston, A. B. (1997). Frontiers of Electronic Commerce. Boston, MA: Addison-Wesley Longman Publishing.

Korgaonkar, P., O’Leary, B., \& Silverblatt, R. (2009). Critical factors to successful website development: opinions of website designers and developers. International Journal of E-Business Research, 5(4), 39-54. DOI: 10.4018/jebr.2009040603.

Lee, Y., \& Kozar, K. A. (2006). Investigating the effect of website quality on e-business success: An analytic hierarchy process (AHP) approach. Decision Support Systems, 42(3), 1383-1401. https://doi.org/10.1016/j.dss.2005.11.005.

Lee, H. H., \& Lee, S. E. (2007). Mobile commerce: An analysis of key success factors. Journal of Shopping Center Research, 14(2), 29-62.

Lee, S., \& Park, Y. (2009). The classification and strategic management of services in e-commerce: Development of service taxonomy based on customer perception. Expert Systems with Applications, 36(6), 9618-9624. https://doi. org/10.1016/j.eswa.2008.08.014.

Leitner, P., \& Grecheni, T. (2008). Collaborative Shopping Networks: Sharing the Wisdom of Crowds in E-Commerce Environments. BLED 2008 Proceedings, 21.

Lee, J. K., Liang, T. P., Turban, D. C., Turban, E., \& King, D. (2015). Electronic commerce: a managerial and social networks perspective. Retrieved from: http://www.springer. com/us/book/9783319587141.

Lin, C. C., \& Lu, H. (2000). Towards an understanding of the behavioral intention to use a web site. International Journal of Information Management, 20(3), 197-208. https://doi. org/10.1016/S0268-4012(00)00005-0.

Li, R., \& Sun, T. (2020). Assessing factors for designing a successful B2C e-commerce website using fuzzy AHP and TOPSIS-Grey methodology. Symmetry, 12(3), 363. https://doi.org/10.3390/ sym 12030363.

Masudin, I., \& Saputro, T. E. (2016, February). Evaluation of B2C website based on the usability factors by using fuzzy AHP \& hierarchical fuzzy TOPSIS. In: IOP Conference Series: Materials Science and Engineering, 114(1), 012091. IOP Publishing Ltd.https://iopscience.iop.org/article/10.1088/1757899X/114/1/012091.

McKinney, V., Yoon, K., \& Zahedi, F. (2002). The measurement of web-customer satisfaction: An expectation and disconfirmation approach. Information System Research, 13(3), 296-315. https:// pubsonline.informs.org/doi/abs/10.1287/isre.13.3.296.76.

Molinillo, S., Anaya-Sánchez, R., \& Liébana-Cabanillas, F. (2020). Analyzing the effect of social support and community factors on customer engagement and its impact on loyalty behaviors toward social commerce websites. Computers in Human Behavior, 108. https://doi.org/10.1016/j.chb.2019.04.004.

Mistry, D., Modi, P., Deokule, K., Patel, A., Patki, H., \& Abuzaghleh, O. (2016, April). Network traffic measurement and analysis. In: 2016 IEEE Long Island Systems, Applications and Technology Conference (pp. 1-7). IEEE. DOI: 10.1109/ LISAT.2016.7494141.

Nagpal, R., Mehrotra, D., Bhatia, P. K., \& Sharma, A. (2015a). Rank university websites using fuzzy AHP and Fuzzy TOPSIS approach on usability. International Journal of Information Engineering and Electronic Business, 7(1), 29-36. DOI: 10.5815/ijieeb.2015.01.04.

Nagpal, R., Mehrotra, D., \& Bhatia, P. K. (2016b). Usability evaluation of website using combined weighted method: fuzzy AHP and entropy approach. International Journal of System Assurance Engineering and Management, 7(4), 408-417. https://doi.org/10.1007/s13198-016-0462-y.

Nguyen, P. H., Tsai, J. F., Kumarg, V. A., \& Hu, Y. C. (2020). Stock investment of agriculture companies in the Vietnam stock exchange market: An AHP integrated with GRA-TOPSISMOORA approaches. Journal of Asian Finance, Economics and Business, 7(7), 113-121. https://doi.org/10.13106/ jafeb.2020.vol7.no7.113.

Pappas, N. (2016). Marketing strategies, perceived risks, and consumer trust in online buying behaviour. Journal of Retailing and Consumer Services, 29, 92-103. https://doi.org/10.1016/j. jretconser.2015.11.007.

Planet, L. (2012). Lonely Planet's Best in Travel: top 10 countries for 2012. Retrieved from: http://www.lonelyplanet.com/traveltips-and-articles/76856\#ixzz3m9nLvnCH. 
Prougestaporn, P., Visansakon, T., \& Saowapakpongchai, K. (2015). Key success factors and evaluation criteria of e-learning websites for higher education. International Journal of Information and Education Technology, 5(3), 233-236. DOI: 10.7763/IJIET.2015.V5.507.

Ramanathan, P. (2002). Location-centric approach for collaborative target detection, classification, and tracking. In: IEEE CAS Workshop on Wireless Communication and Networking (Invited). Sept. 5-6. https://core.ac.uk/display/24600387.

Rau, P. L. P., Chen, J. \& D. Chen, D. (2006). A study of presentations of mobile web banners for location-based information and entertainment information websites. Behaviour \& Information Technology, 25(3), 253-261. https:// doi.org/10.1080/01449290500222009.

Rockart, J. F. (1979). Chief executives define their own data needs. Harvard Business Review, 57(2), 81-93. https://hbr. org/1979/03/chief-executives-define-their-own-data-needs.

Rosenfeld, L., \& Morville. (1997). Information architecture for the world wide web: Designing large-scale web sites. O'Reilly. https://www.amazon.com/Information-Architecture-WorldWide-Web/dp/059652734.

Robin, P., Wilxon, H. D., \& Grover, V. (2004). The role of system trust in Business-to-Consumer transactions. Journal of Management Information Systems, 20(3), 197-226. https://doi. org/10.1080/07421222.2003.11045777.

Roy, J., Chatterjee, K., Bandyopadhyay, A., \& Kar, S. (2018). Evaluation and selection of medical tourism sites: A rough analytic hierarchy process based multi-attributive border approximation area comparison approach. Expert Systems, 35(1), 1-19. https://doi.org/10.1111/exsy.12232.

Rouyendegh, B. D., Topuz, K., Dag, A., \& Oztekin, A. (2019). An AHP-IFT integrated model for performance evaluation of e-commerce web sites. Information Systems Frontiers, 21(6), 1345-1355. https://link.springer.com/article/10.1007/s10796018-9825-z.

Saaty, T. L. (1977). A scaling method for priorities in a hierarchical structures. Journal of Mathematical Psychology, 15(3), 234281. https://doi.org/10.1016/0022-2496(77)90033-5.

Saaty, T. L. (1986). Axiomatic foundation of the analytic hierarchy process. Management Science, 32(7), 841-855. https://doi. org/10.1287/mnsc.32.7.841.

Sahi, G. (2015, August). User satisfaction and website usability: exploring the linkages in $\mathrm{B} 2 \mathrm{C}$ e-commerce context. In: $20155^{\text {th }}$ International conference on IT convergence and security (pp. 1-4). IEEE. DOI: 10.1109/ICITCS.2015.7293034.

Sariçali, G., \& Kundakci, N. (2016). Evaluation of hotel alternatives with the AHP and COPRAS methods. International Review of Economics and Management, 4(1), 45-66. DOI: 10.18825/ irem.00736.
Shchiglik, C., \& Barnes, S. J. (2004). Evaluating website quality in the airline industry. Journal of Computer Information Systems, 44(3), 17-25.

Sindhu, S., Nehra, V., \& Luthra, S. (2017). Investigation of feasibility study of solar farms deployment using hybrid AHP-TOPSIS analysis: Case study of India. Renewable and Sustainable Energy Reviews, 73, 496-511. https://doi. org/10.1016/j.rser.2017.01.135.

Singh, N., Krishnamurthy, S., Luo, Y., Zhao, J. H., \& Du, J. (2005). The internationalization speed of e-commerce companies: an empirical analysis. International Marketing Review, 22(6), 693-709. https://doi.org/10.1108/02651330510630294.

Stover, J. S. (2007). Making marketing work for your library blog. Internet Reference Services Quarterly, 11(4), 155-167. https:// doi.org/10.1300/J136v11n04_10.

Trang, T. V., \& Do, Q. H. (2020). Critical success factors of TQM implementation in Vietnamese supporting Industries. Journal of Asian Finance, Economics and Business, 7(7), 391-401. https://doi.org/10.13106/jafeb.2020.vol7.no7.391.

Wan, H. A. (2000). Opportunities to enhance a commercial website. Information \& Management, 38(1), 15-21. https://doi. org/10.1016/S0378-7206(00)00048-3.

Wan, C. S. (2002). The web sites of international tourist hotels and tour wholesalers in Taiwan. Tourism Management, 23(2), 155160. https://doi.org/10.1016/S0261-5177(01)00048-6.

Wang, Y., \& Fesenmaier, R. D. (2006). Identifying the success factors of web-based marketing strategy: An investigation of convention and visitors bureaus in the united states. Journal of Travel Research, 44(3), 239-249. https://journals.sagepub.com/ doi/abs/10.1177/0047287505279007.

White, G. P. (1987). The implementation of management science in higher education administration. Omega, 15(4), 283-290. https://doi.org/10.1016/0305-0483(87)90016-8.

Wright, L. T., Pires, G. D., Stanton, J., \& Rita, P. (2006). The internet, consumer empowerment and marketing strategies. European Journal of Marketing, 40(9/10), 936-949. https://doi. org/10.1108/03090560610680943.

Yang, D. J., Chou, D. H., \& Liu, J. (2012). A study of key success factors when applying e-commerce to the travel industry. International Journal of Business Social Science, 3(8), 114119.

Yu, X., Guo, S., Guo, J., \& Huang, X. (2011). Rank B2C e-commerce websites in e-alliance based on AHP and fuzzy TOPSIS. Expert Systems with Applications, 38(4), 3550-3557. https://doi.org/10.1016/j.eswa.2010.08.143.

Zhou, Q., Huang, W., \& Zhang, Y. (2011). Identifying critical success factors in emergency management using a fuzzy DEMATEL method. Safety Science, 49(2), 243-252. https://doi. org/10.1016/j.ssci.2010.08.005. 